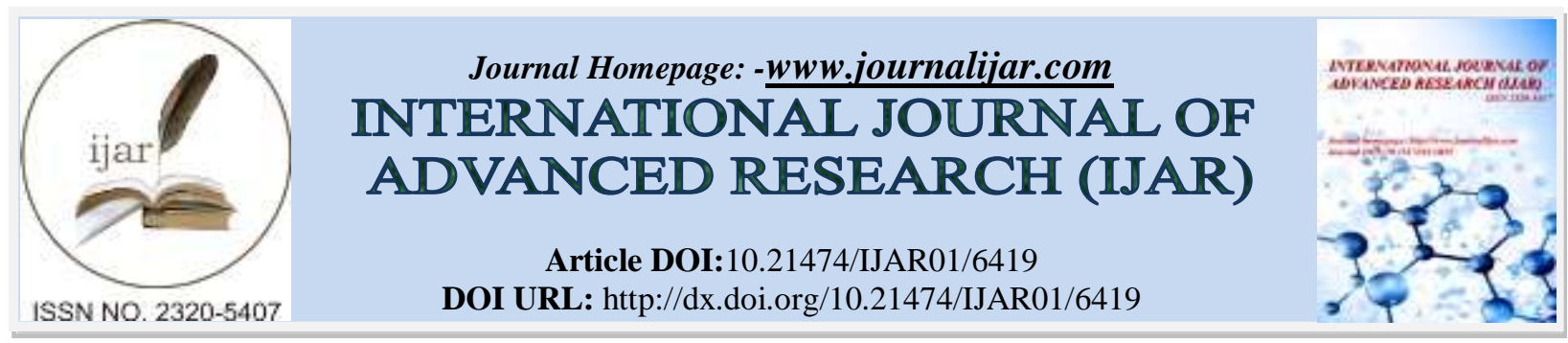

RESEARCH ARTICLE

\title{
COMPARATIVE STUDY ON METHANOLIC AND CHLOROFORM EXTRACTS OF TRACHYSPERMUM AMMI SEEDS FOR ANTIARTHRITIC AND ANTIGOUT ACTIVITY.
}

S Ramachandran, J Nikitha, K Srujana, G AtchuthRayudu and Y Aruna.

Department of Pharmacology, GIET School of Pharmacy, Rajahmundry, Andhra Pradesh, India.

\section{Manuscript Info}

Manuscript History

Received: 02 December 2017

Final Accepted: 04 January 2018

Published: February 2018

Keywords:-

Anti-arthritic,Anti-gout, Trachyspermum ammi, Folinciocalteu reagent.

\begin{abstract}
Objective: The objective of the present study is to report the in vitro anti-arthritic and anti-gout activity of methanolic and chloroform extract of Trachyspermum ammi seeds.

Materials and Methods: Fresh Trachyspermum ammi seeds were collected and extracted by using methanol and chloroform solvent by successive soxhelation for the constituents. Preliminary phytochemical screening has been done. Methanolic extract was tested for its polyphenolic content by Folin-ciocalteu's reagent. In vitro anti-arthritic activity was performed by inhibition of protein denaturation method. In vitro anti-gout activity was performed by the metal chelating complex assay.

Results: The study showed the presence of cardiac glycosides, carbohydrates, phytosterols, saponins, phenolic and tannins in the methanolic extract. Alkaloids, saponins, phenolics, tannins, carbohydrates in chloroform extract. The methanolic extract showed significant anti-arthritic activity than chloroform extract, this might be due to methanolic extract was rich in polyphenols. The anti-gout activity of Trachyspermum ammi seeds methanolic extract was also observed to be highly significant in its activity.

Conclusion: Both the methanolic and chloroform extracts of Trachyspermum ammi seeds were found to have significant antiarthritic and anti-gout activity when compared to standard drug diclofenac in a dose-dependent manner.
\end{abstract}

Copy Right, IJAR, 2018,. All rights reserved.

\section{Introduction:-}

Arthritis is an inflammation of the joints. Arthritis is considered to be secondary to the main disease, these include Psoriasis (Psoriatic arthritis), Reactive arthritis, Ehlers-danlos syndrome, Hemochromatosis, Hepatitis, Lyme disease, Sjogren's disease, Hashimoto's Thyroiditis etc. Other frequently occurring forms of arthritis include rheumatoid arthritis, lupus, fibromyalgia, and gout ${ }^{1}$. Inflammatory cells involved in rheumatoid arthritis include $\mathrm{CD}^{4}$ helper cells, $\beta$-cells, macrophages and plasma cells. Key cytokines involved in rheumatoid arthritis include tumor necrosis factor (TNF- $\alpha$ ), interleukin-1, interleukin-6 and granulocyte macrophage-colony stimulating factor(GM$\mathrm{CSF})^{2}$. Tests for the presence of Anti-citrullinated protein antibodies (ACPA) by anti-CCP(cyclic citrullinated peptide) test and anti-MCV assay(antibodies against mutated citrullinated vimentin) ${ }^{3}$.

Corresponding Author:-S Ramachandran.

Address:-Department of Pharmacology, GIET School of Pharmacy, Rajahmundry, Andhra Pradesh, 
Gout is usually characterized by recurrent attacks of inflammatory arthritis a red, tender, hot and swollen joint ${ }^{4}$. The joint at the base of the big toe is affected in about half of cases. The underlying mechanism involves elevated levels of uric acid in the blood ${ }^{5}$. When the uric acid crystallizes and the crystal deposits in joints, tendons, and surrounding tissues than an attack of gout occurs ${ }^{6}$. Diagnosis may be confirmed by seeing the characteristic crystals in joint fluid or tophus. Treatment with NSAIDs, steroids or colchicines improves symptoms ${ }^{7}$. Long-standing elevated uric acid levels (hyperuricemia) may result in other symptomatology including hard, painless deposits of uric acid crystals known as tophi ${ }^{8}$. Lesch-Nyhan syndrome is often associated with gouty arthritis. Urate is the end product of purine metabolism. In recent years important urate transporter proteins such as the human URAT1 transporter (hURAT1) and the fructose transporter SCL2A9 have been characterized. Urate crystals lead to activation of the NALP3 inflammasome with the release of proinflammatory cytokines among them interleukins 1,18 and 8 of the tumor necrosis factor attracting more polymorphonuclear neutrophilic granulocytes (e10-e12) .

Trachyspermum ammi seeds have been widely used as a traditional medicine for many diseases like cholera, diarrhea, atonic dyspepsia, indigestion, flatulence, cold, flu and other viral infections. It can be used as tonic, diuretic, expectorant, relaxes spasms and increases perspiration. Ajwain seeds contain about $50 \%$ thymol, a well known antibacterial essential oil, along with thyme can be used to enhance the immune system.

\section{Materials and Methods:-}

\section{Collection and extraction of medicinal plant material}

Fresh seeds of Trachyspermum ammi seeds were collected from East Godavari district (A.P) in the months of DecJan 2016. The trailing herb was authenticated by Dr.J.Suneetha, Dept.of Botany, Govt Art's College, Rajahmundry, A.P., and Reference: Glossary of the presidency of Madras by Gambel, Pg.no 559, Vol-1. Collected seeds were shade dried and made into the coarse powder with the use of mixer grinder. The powder was weighed and stored.

\section{Soxhelation procedure:}

Seeds were extracted with methanol and chloroform by successive soxhelation for the constituents. 200 gram of airdried powdered material drug was successively separated in Soxhlet apparatus using methanol followed by chloroform. Each time before extraction with next solvent the powdered material was air-dried. All the extracts were concentrated by distilling the solvent and evaporating them to dryness at low temperature. They were then weighed and the percentage of different extractive values were calculated in term of air dried weight of the plant material. Thentheextractobtained was vacuum dried by placing it in a Petri-plate on electric water bath $\left(70^{\circ} \mathrm{C}\right)$, kept in an oven at $30^{\circ} \mathrm{C}$ for $2 \mathrm{hrs}$. The obtained extract was stored in a vacuum desiccator.

\section{Estimation of Polyphenolic Contents:- \\ Reagents:}

Methanolic extract was tested for its polyphenolic content. The colorimetric procedure described was followed. This is based on the principle that polyphenols give a blue color chromogen in alkaline medium with Folin- Ciocalteu's reagent, having absorption maxima at $720 \mathrm{~nm}$.

\section{Procedure:}

The total soluble phenolic contents in seaweed were determined with Folin Ciocalteu reagent. To each of the seaweed extracts $(100 \mu \mathrm{g} / \mathrm{ml}), 1 \mathrm{ml}$ of Folin Ciocalteu reagent $(1: 10 \mathrm{v} / \mathrm{v})$ was added and incubated at room temperature for 5 minutes. $1 \mathrm{ml}$ of $7 \%$ sodium carbonate solution was added and incubated at room temperature for 90 minutes. The absorbance was measured at $720 \mathrm{~nm}$ using UV spectrophotometer. The same procedure was carried out for gallic acid $(0.2-1 \mathrm{mg} / \mathrm{ml})$ standard. The total phenol content of the extracts was obtained by using the standard curve. The total phenol content was expressed as gallic acid equivalent in $\%$, w/w of the extracts ${ }^{10}$.

\section{In-vitro anti-arthritic activity by inhibition of protein denaturation method:-}

The test solution $(0.5 \mathrm{ml})$ consist of $0.45 \mathrm{ml}$ of Bovine serum albumin $(5 \% \mathrm{~W} / \mathrm{V}$ aqueous solution) and $0.05 \mathrm{ml}$ of test solution $(250 \mu \mathrm{g} / \mathrm{ml})$.

Test control solution $(0.5 \mathrm{ml})$ consist of $0.45 \mathrm{ml}$ of bovine serum albumin $(5 \% \mathrm{~W} / \mathrm{V}$ aqueous solution) and $0.05 \mathrm{ml}$ of distilled water.

Product control $(0.5 \mathrm{ml})$ consist of $0.45 \mathrm{ml}$ of distilled water and $0.05 \mathrm{ml}$ of test solution $(250 \mu \mathrm{g} / \mathrm{ml})$.

Standard solution $(0.5 \mathrm{ml})$ consist of $0.45 \mathrm{ml}$ of Bovine serum albumin $(5 \% \mathrm{w} / \mathrm{v}$ aqueous solution) and $0.05 \mathrm{ml}$ of Diclofenac sodium $(250 \mu \mathrm{g} / \mathrm{ml})$. 
All the above solutions were adjusted to $\mathrm{pH} 6.3$ using $1 \mathrm{~N} \mathrm{HCl}$. The samples were incubated at $37^{\circ} \mathrm{c}$ for 20 minutes and the temperature was increased to keep the samples at $57^{\circ} \mathrm{c}$ for 3 minutes. After cooling, $2.5 \mathrm{ml}$ of phosphate buffer was added to the above solutions. The absorbance was measured using UV-Visible spectrophotometer at $416 \mathrm{~nm} .{ }^{[11-12]}$ The percentage inhibition of protein denaturation can be calculated as,

Percentage inhibition $=[100-($ optical density of test solution - optical density of product control $) \div($ optical density of test control) $] \times 100$.

The control represents $100 \%$ protein denaturation. The results were compared with standard Diclofenac sodium $(250 \mu \mathrm{g} / \mathrm{ml}){ }^{11}$

\section{Anti-gout activity:}

\section{Metal chelating complex assay:-}

The reaction mixture containing $1 \mathrm{ml}$ of different concentrations of extracts $10,20,40,80,100$ and $120 \mu \mathrm{g} \mathrm{ml}{ }^{-1}$ in methanol was added to $0.1 \mathrm{ml}$ of $2 \mathrm{mM}$ ferrous chloride and $0.2 \mathrm{~mL}$ of $\mathrm{mM}$ Ferrozine to initiate the reaction and the mixture was shaken vigorously and left to stand at room temperature for $10 \mathrm{~min}$. The absorbance of the solution was measured at $562 \mathrm{~nm}$. The positive controls were those using ascorbic acid and all tests were run in triplicate. The percentage chelating effect of Ferrozine $\mathrm{Fe}_{2+}$ complex formation was calculated from ${ }^{12}$

$$
\frac{A_{\mathrm{o}}-A 1}{A_{\mathrm{o}}} \times 100
$$

$\mathrm{A}_{\mathrm{o}}$ is the absorbance of the control

$\mathrm{A}_{1}$ is the absorbance of extract or standard

\section{Results:-}

\section{Percentage yield of the extract:}

Seeds of Trachyspermum ammi were selected for the present study. The crude drug was powdered and extracted with methanol to study the constituents present. The nature of extracts and their extractive values are reported in the following Table.1.

Table 1: Percentage yield of the extract

\begin{tabular}{|c|c|c|c|}
\hline DRUGS & SOLVENT & COLOUR & \% EXTRACTIVE VALUES \\
\hline \multirow{2}{*}{ Trachyspermum ammi } & Alcohol (95\%) & Dark brown & 11.5 \\
\cline { 2 - 4 } & Chloroform & Brownish & 6 \\
\hline
\end{tabular}

\section{Estimation of Polyphenolic Contents:}

The total phenolic content of hydro methanolic extract of Trachyspermum ammi seed was calculated as Gallic acid equivalent of phenols. Free radicals are produced under certain environmental conditions and during the normal cellular function in the body; these molecules are missing an electron, giving them an electric charge. To neutralize this charge, free radicals try to withdraw an electron from, or donate an electron to, a neighboring molecule. The newly created free radical in turn look out for another molecules and withdraws or donates an electron, setting off a chain reaction that can damage hundreds of molecules. The total phenol content shows good linear relation in both standard as well as sample extracts. Phenolic compounds are important plant constituents because their hydroxyl groups confer scavenging ability.

Table 2: Absorbance data of polyphenols in Gallic acid as standard

\begin{tabular}{|c|c|}
\hline Conc. $(\boldsymbol{\mu g} / \mathbf{m l})$ & Gallic Acid \\
\hline 25 & 0.579 \\
\hline 50 & 0.669 \\
\hline 100 & 0.776 \\
\hline 150 & 0.868 \\
\hline 200 & 0.948 \\
\hline
\end{tabular}


Fig. 1: Absorbance \& concentration of Gallic acid

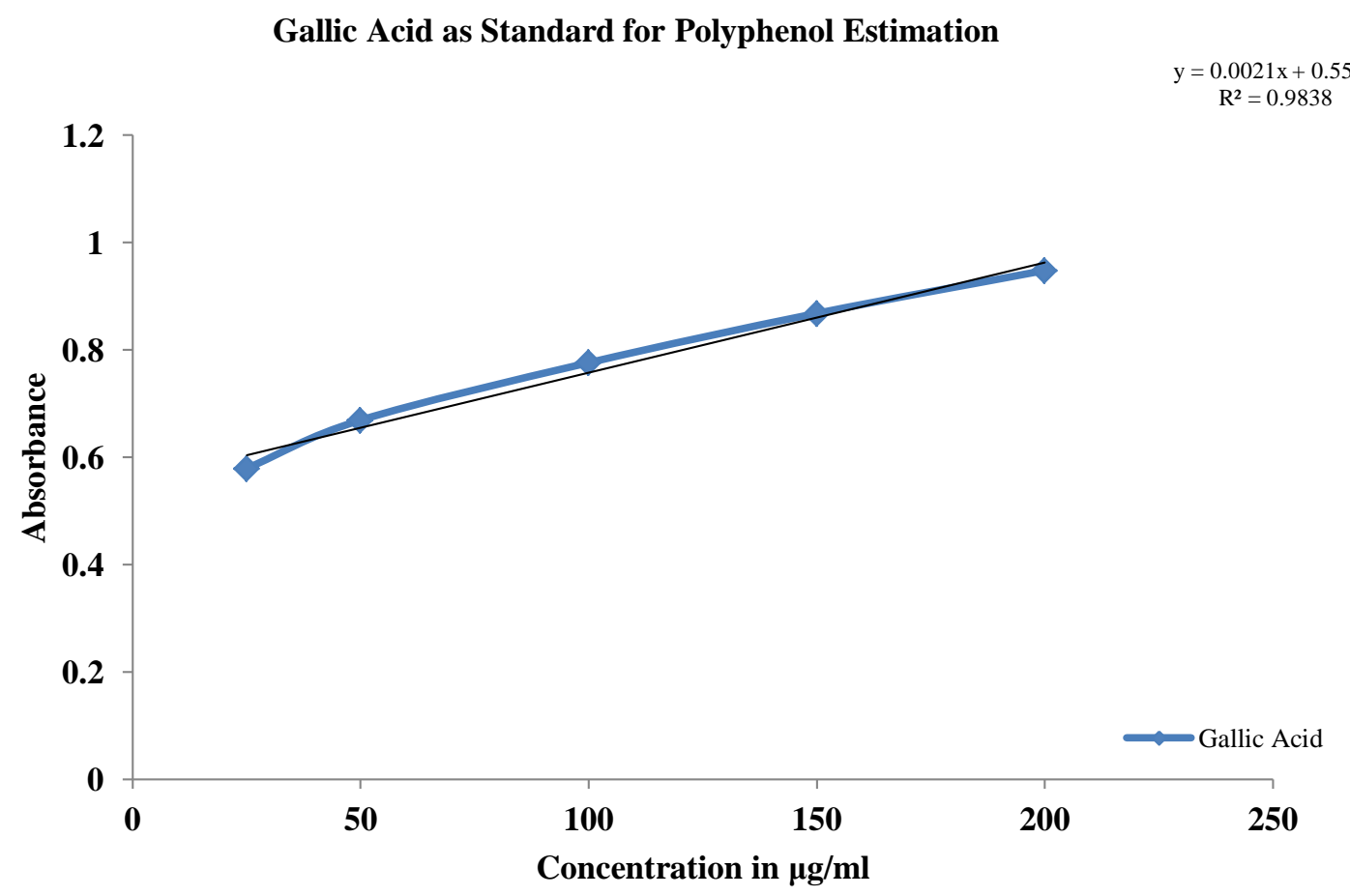

Taking into consideration from the graph, the methanolic\& chloroform extracts were found to contain $63.5 \mu \mathrm{g} / \mathrm{ml}$, $30.5 \mu \mathrm{g} / \mathrm{ml}$ of polyphenols equivalent to Gallic acid

Table 3:- Polyphenol Content of extracts equivalent to Gallic acid

\begin{tabular}{|c|c|c|}
\hline S.No. & Extracts & Gallic acid Equiv. in $\boldsymbol{\mu g} / \mathbf{m l}$ \\
\hline 1. & Methanolic Ext. & 63.5 \\
\hline 2 & Chloroform Ext. & 30.5 \\
\hline
\end{tabular}

In-vitro anti-arthritic activity:

The methanolic and chloroform extracts of Trachyspermum ammi seeds showed good inhibitory activity on protein denaturation with the $\mathrm{IC}_{50}$ value of $105.69 \mu \mathrm{g} / \mathrm{ml}$ for methanolic extract and $134.5 \mu \mathrm{g} / \mathrm{ml}$ for chloroform extract as compared to standard Diclofenac having $\mathrm{IC}_{50}$ value $86.73 \mu \mathrm{g} / \mathrm{ml}$.These results were shown in Table-4. Percentage inhibition of protein denaturation of methanolic \& chloroform seed extracts of Trachyspermum ammi was shown in fig.2. 
Fig. 2:- Percentage of protein denaturation inhibition of Trachyspermum ammi seeds extract

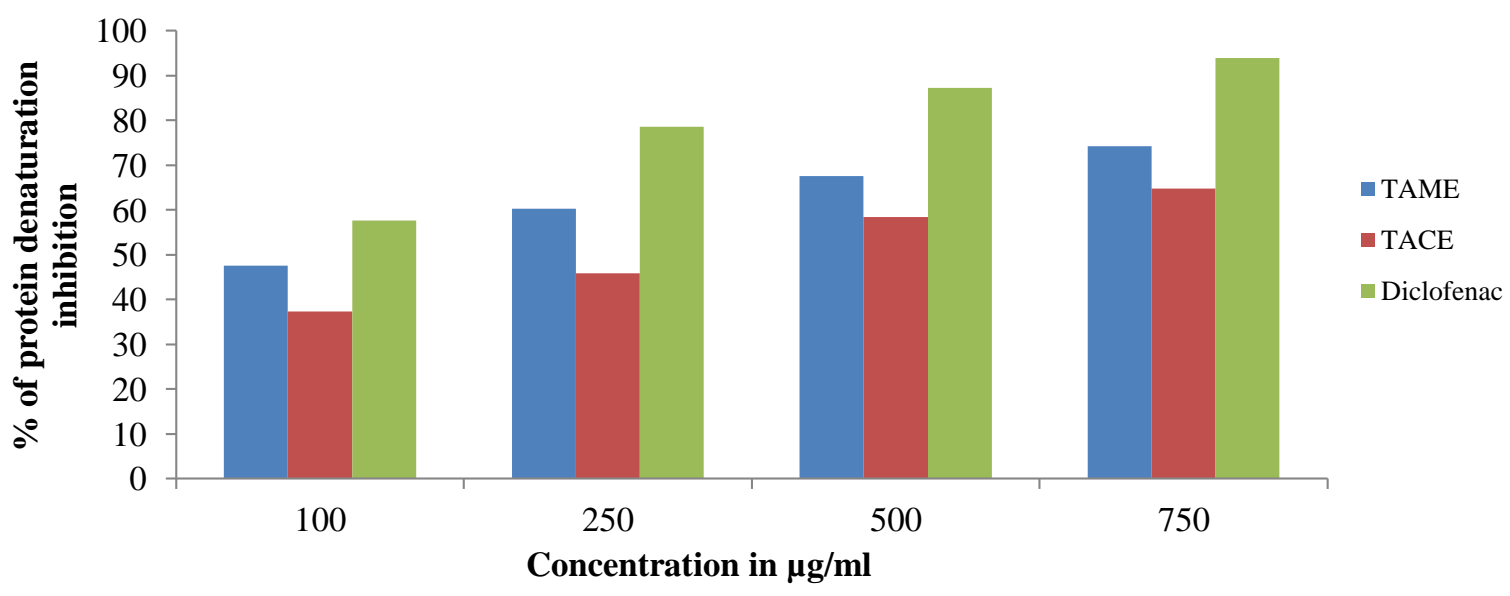

TAME-Trachyspermum ammi seeds Methanolic extract TACE-Trachyspermum ammi seeds Chloroform extract

Table 4:- Anti-arthritic activity of methanolic \& chloroform seed extracts of Trachyspermum ammi

\begin{tabular}{|c|c|c|c|c|}
\hline S.No & Test extract & Dose $(\mu \mathrm{g} / \mathrm{ml})$ & \% inhibition & $I_{50}(\mu \mathrm{g} / \mathrm{ml})$ \\
\hline \multirow{4}{*}{1} & \multirow{4}{*}{ TAME } & 100 & 47.6 & \multirow{4}{*}{105.69} \\
\hline & & 250 & 60.3 & \\
\hline & & 500 & 67.5 & \\
\hline & & 750 & 74.2 & \\
\hline \multirow{4}{*}{2} & \multirow{4}{*}{ TACE } & 100 & 37.3 & \multirow{4}{*}{134.5} \\
\hline & & 250 & 45.8 & \\
\hline & & 500 & 58.4 & \\
\hline & & 750 & 64.7 & \\
\hline \multirow{4}{*}{3} & \multirow{4}{*}{ Diclofenac } & 100 & 57.6 & \multirow{4}{*}{86.73} \\
\hline & & 250 & 78.5 & \\
\hline & & 500 & 87.2 & \\
\hline & & 750 & 93.9 & \\
\hline
\end{tabular}

TAME-Trachyspermum ammi seeds Methanolic extract

TACE-Trachyspermum ammi seeds Chloroform extract

Invitro anti-gout activity:

The methanolic and chloroform extracts of Trachyspermum ammi seed were evaluated for anti-gout activity by the metal chelating complex assay which shows the $\mathrm{IC}_{50}$ value of $255.05 \mu \mathrm{g} / \mathrm{ml}$ for methanolic extract and $510 \mu \mathrm{g} / \mathrm{ml}$ for chloroform extract and $\mathrm{IC}_{50}$ value $142 \mu \mathrm{g} / \mathrm{ml}$ for Diclofenac.These results were shown in Table-5. Percentage inhibition of protein denaturation of methanolic and chloroform seed extracts of Trachyspermum ammi seed was shown in fig. 3. 
Fig. 3:- Percentage Metal chelating effect of Trachyspermum ammi seeds

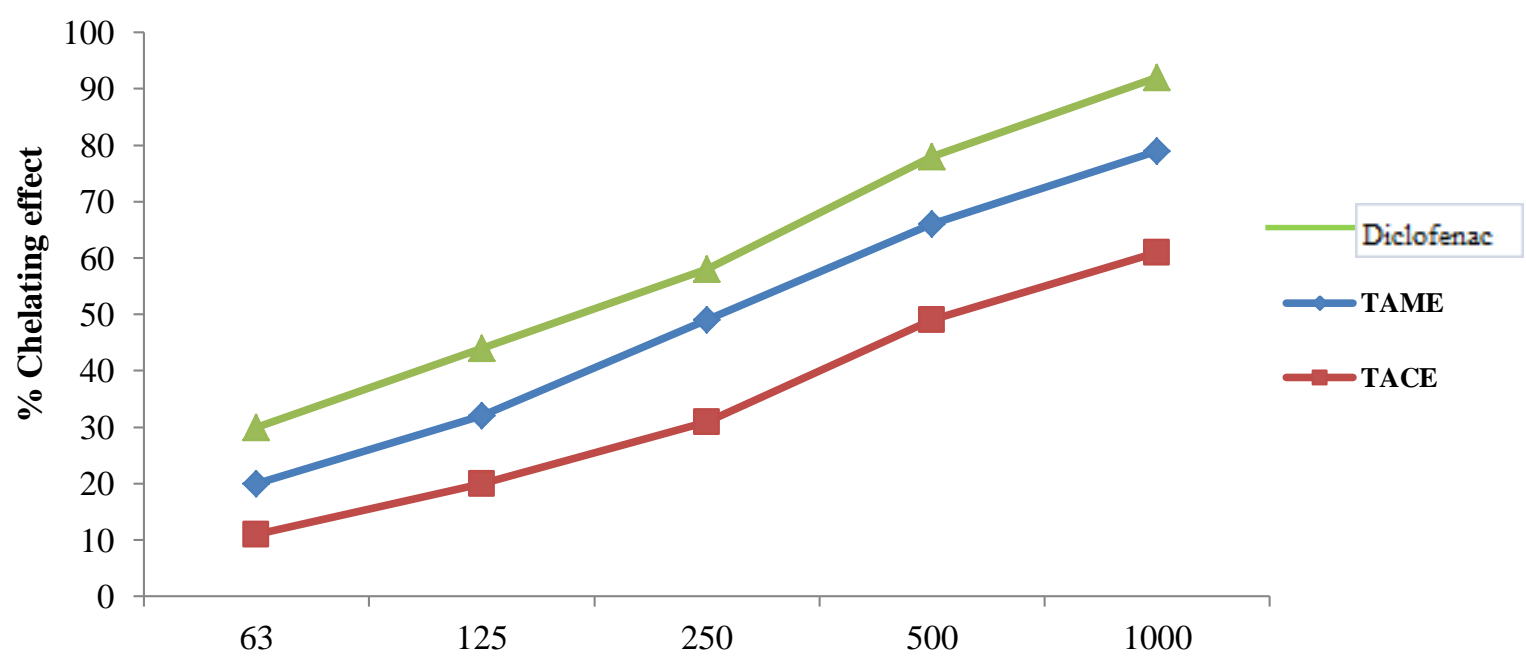

Concentration $(\mu \mathrm{g} / \mathrm{ml})$

Table-5: Anti-gout activity of methanolic \& chloroform seeds extracts of Trachyspermum ammi

\begin{tabular}{|c|c|c|c|c|}
\hline S.No & Test extract & Dose $(\mu \mathrm{g} / \mathrm{ml})$ & \% inhibition & IC50 $(\mu \mathrm{g} / \mathrm{ml})$ \\
\hline \multirow{5}{*}{1} & \multirow{5}{*}{ TAME } & 63 & 20 & \multirow{5}{*}{255.05} \\
\hline & & 125 & 32 & \\
\hline & & 250 & 49 & \\
\hline & & 500 & 66 & \\
\hline & & 1000 & 79 & \\
\hline \multirow{5}{*}{2} & \multirow{5}{*}{ TACE } & 63 & 11 & \multirow{5}{*}{510} \\
\hline & & 125 & 20 & \\
\hline & & 250 & 31 & \\
\hline & & 500 & 49 & \\
\hline & & 1000 & 61 & \\
\hline \multirow{5}{*}{3} & \multirow{5}{*}{ Diclofenac } & 63 & 30 & \multirow{5}{*}{142} \\
\hline & & 125 & 44 & \\
\hline & & 250 & 58 & \\
\hline & & 500 & 78 & \\
\hline & & 1000 & 92 & \\
\hline
\end{tabular}

TAME-Trachyspermum ammi seeds Methanolic extract

TACE-Trachyspermum ammi seeds Chloroform extract

\section{Discussion:-}

Arthritis is an inflammation of the joints. It can affect one joint or multiple joints. Pathologically, rheumatoid arthritis is characterized by the infiltration of a variety of inflammatory cells into the joint. Gout is a disorder characterized by hyperuricemia and deposition of urate crystals in the synovial joints. Recent studies have clearly demonstrated the importance of medicinal plants in the treatment of many pathological diseases including arthritis \& gout.

\section{Preliminary phytochemical screening:}

Seeds of Trachyspermum ammi were selected for the present study. The drugs were powdered and successively extracted with methanol and chloroform to study the constituents present in them. The successive extracts of the 
drug were analyzed for the presence of various constituents. The result of our study on Trachyspermum ammi revealed the presence of amino acids in its chloroform extract and presence of alkaloids, carbohydrates, phytosterols, flavonoids and tannins in its methanolic extracts.

\section{Determination of total polyphenols:}

Both the extracts of Trachyspermum ammi seeds were tested for their polyphenolic content using Folin-Ciocalteu reagent using the colorimetric procedure. Many researchers have used this method to correlate the antioxidant activity of extracts to the phenolic content. This method has been used in the wine industry for over 30 years and is considered to be the best method for estimating total phenol content in complex plant products. This method is the sensitive and quantitative method, independent of the degree of polymerization compared to other methods.

The total polyphenolic content in all the extracts is expressed in terms of Gallic acid equivalent. In accordance with this report, our study indicates $63.5 \mu \mathrm{g} / \mathrm{ml}$ of GAE of polyphenols in the methanolic extract, whereas only 30.5 $\mu \mathrm{g} / \mathrm{ml}$ of GAE in chloroform extracts. When compared to the results of two extracts, it reveals that the phenolic content was more with methanolic extract as compared to the chloroform extract. Using these results, levels of total polyphenols in extracts were correlated to their respective antioxidant capacity.

\section{Screening of anti arthritic activity:}

The methanolic and chloroform extracts are having an anti-arthritic potential to retard the arthritic protein denaturation, which is proving its usefulness in arthritis treatment. Percentage inhibition of protein denaturation activity of methanolic extract showed maximum inhibitory activity comparing to chloroform extract of Trachyspermum ammi seeds, when compared to standard Diclofenac. The Percentage inhibition of protein denaturation in terms of percentage of protection was increased in a dose-dependent manner.

\section{Screening of anti-gout activity:}

The anti-gout activity was evaluated for the metal chelating complex assay for both methanolic and chloroform extract. It was found that the percentage chelating effect is maximum for Diclofenac followed by the methanolic extract. This is evidence that the methanolic extract of Trachyspermum ammi seed is having anti-gout activity. The Percentage of chelating effect was increased in a dose-dependent manner.

\section{Conclusion:-}

In vitro studies on Trachyspermum ammi seeds extract demonstrate suppression of both arthritis and gout. Methanolic extract of Trachyspermum ammi seeds is a rich source of polyphenols, responsible for its significant anti- arthritic activity as compared to chloroform extract. Therefore from the present study, it can be suggested that Trachyspermum ammi seeds methanolic extract was proved to have anti-arthritic and anti-gout activity as compared to the standard Diclofenac, both activities are exerting in a dose-dependent manner.

The preliminary screening study showed the presence of alkaloids, carbohydrates, flavonoids, fixed oils, fats, phenolics, tannins in methanolic extract and alkaloids, saponins, carbohydrates, amino acids in chloroform extract. Hence proper isolation of the active principles might help in the findings of new lead compounds in the fields of anti-arthritic and anti-gout drug research. This study thus provided justification for the traditional usage of Trachyspermum ammi seeds for the treatment of arthritis, gout and may be recommended as a supplement with synthetic drugs.

Conflicts of Interest: There are no conflicts of interest. 


\section{References:-}

1. Pankaj S, Kothavade, Vipin D. Bulani, Padmini S. Deshpande, Amrita S. Chowdhury, Archana R. Juvekar.: The petroleum ether fraction of Celastruspaniculatus Wild. seeds demonstrates Antiarthritic effect in adjuvantinduced arthritis in rats. Journal of Traditional Chinese Medical Sciences; 2, 183-193, (2015)

2. Toru Ishibashi.: Molecular Hydrogen: New Antioxidant and Anti-inflammatory Therapy for Rheumatoid Arthritis and Related Diseases. Current Pharmaceutical Design; 19, 6375-6381, (2013).

3. Tsutomu Takeuchi, Nobuyuki Miyasaka, Takashi Inui, Toshiro Yano, Toru Yoshinari, Tohru Abe and Takao Koike.: High titers of both rheumatoid factor and anti-CCP antibodies at baseline in patients with rheumatoid arthritis are associated with increased circulating baseline TNF level, low drug levels, and reduced clinical responses: a post hoc analysis of the RISING study. 19:194, (2017).

4. Hanaa S. M. Abd El-Rahman, Nasra A. M. Abd-ELHak: Xanthine Oxidase Inhibitory Activity and Antigout of Celery Leek Parsley and Molokhia. Advances in Biochemistry. Vol. 3, No. 4, 40-50, (2015).

5. Agustin yumita1, asepgana suganda1, elinyulinah sukandar1: Xanthine oxidase inhibitory activity of some indonesian medicinal plants and active fraction of selected plants. International Journal of Pharmacy and Pharmaceutical Sciences. Vol 5, Suppl 2, (2013).

6. Doha A. Mohamed, Sahar Y. Al-Okbi.: Evaluation of anti-gout activity of some plant food extracts, Pol. J. Food Nutr. Sci. Vol. 58, No. 3, pp. 389-395, (2008).

7. X. Ling, W. Bochu:A review of phytotherapy of gout: perspective of new pharmacological treatments. 243256, (2014).

8. Yan Gang Wang, Luan Wang, EnZe Li, Yang Li, ZhongChao Wang, XiaoFang Sun, XiaoLong Yu, Lin Ma, YunLong Wang, YouXin Wang Chuanhu: Anti-Gout Mixture versus Colchicine for Acute Gouty Arthritis: A Randomized, Double-Blind, Double-Dummy, Non-Inferiority Trial. International Journal of Medical Sciences. 11(9): 880-885, (2014).

9. Sarvaiya VN, Sadariya KA, Pancha PG, Thaker AM, Patel AC, Prajapati AS: Evaluation of Antigout activity of Phyllanthusemblicafruit extracts on potassium oxonate induced gout rat model. Veterinary World. 8(10):12301236, (2015).

10. Manoj Kumar Narasimhan, Shenoy K Pavithra, Vishnupriya Krishnan, and MuthukumaranChandrasekaran: In vitro Analysis of Antioxidant, Antimicrobial and Antiproliferative Activity of Enteromorpha antenna, Enteromorphalinza and Gracilariacorticata Extracts. Jundishapur J Nat Pharm Prod. 8(4): 151-159, (2013).

11. R Lavanya, S Uma Maheshwari, G Harish, J Bharath Raj, S Kamali, D Hemamalani, J BharathVarma, C Umamaheswara Reddy: Investigation of In-vitro anti-Inflammatory, anti-platelet and anti-arthritic activities in the leaves of AnisomelesmalabaricaLinn. RJPBCS. 1(4). 745, (2010).

12. Neeruvasudeva, PrernaSingla, Sneha Das and Surendra Kumar Sharma: Antigout and Antioxidant activity of stem and root of Origanummajorana Linn. American Journal of Drug Discovery and Development. 4(2): 102112, (2014). 